\title{
Metabolism of Lactose by Intestinal Mucosa from Normal and Lactase-deficient Subjects
}

\author{
D. R. LONDON,*† D.M. ; P. CUATRECASAS,* M.D. ; S. J. BIRGE, Jun.,*¥ M.D.; S. SEGAL,*§ M.D.
}

Brit.med. .., 1967, 1, 524-526

Although many studies have been devoted to a delineation of the clinical syndrome of isolated lactase deficiency in the adult (Cuatrecasas et al., 1965 ; Haemmerli et al., 1965; McMichael et al., 1965 ; Peternel, 1965 ; Sheehy and Anderson, 1965 ; Cook and Kajubi, 1966), to the in-vivo metabolism of lactose in this syndrome (Durand, 1964 ; Cuatrecasas et al., 1965), and to the characteristics of the enzymes whose absence is responsible for the disorder (Dahlqvist et al., 1963 ; Semenza et al., 1965 ; Hsia et al., 1966), there have been no investigations of the cellular transport and metabolism of lactose by the small intestine in lactase deficiency.

Miller and Crane (1961a, 1961b) have shown that disaccharides, particularly sucrose and maltose, are hydrolysed at the brush border of the hamster intestinal epithelial cell and that the products of hydrolysis are either actively transported into the cell or diffuse into the intracellular compartment. These workers were unable to show that intact disaccharides could be concentrated in the mucosal cell. On the other hand, Escherichia coli possess transport systems which facilitate the entry of unchanged galactosides without the necessity for prior hydrolysis (Rickenberg et al., 1956 ; Cohen and Monod, 1957).

It therefore seemed important to study the cellular handling of lactose in isolated lactase deficiency to determine if disaccharide accumulation could occur in the mucosal cell of the human small intestine in the absence of the hydrolytic enzyme.

\section{Methods}

A Rubin tube (Brandborg et al., 1959) was used to perform peroral biopsies of the small-intestinal mucosa. The capsule was positioned immediately proximal to the ligament of Treitz by fluoroscopy with image intensification. Soon after the tissue had been obtained it was placed in oxygenated Krebs-Ringer bicarbonate buffer and kept at $4^{\circ} \mathrm{C}$. The mucosa was then laid out on filter paper and cut into segments weighing approximately 1-3 mg. ; usually 10 such pieces could be obtained from any one biopsy.

Incubations were carried out for periods of 5 to 90 minutes with 1-3 mg. of tissue in $2 \mathrm{ml}$. of oxygenated Krebs-Ringer bicarbonate buffer at $p \mathrm{H} 7.4$ containing lactose $-1-{ }^{14} \mathrm{C}$ as tracer and enough non-radioactive lactose to make a final concentration of $2 \mathrm{mM}$.

Distribution ratios of radioactivity between intracellular water and the incubation medium were determined by methods previously described (Rosenberg et al., 1961). Total cell water and "trapped" extracellular water were found to be the same in control and lactase-deficient subjects. All experiments were performed in duplicate.

* Clinical Endocrinology Branch, National Institute of Arthritis and Metabolic Diseases, National Institutes of Health, Bethesda, Maryland, U.S.A.

† In receipt of a Medical Research Council Travelling Fellowship. Present address: St. Thomas's Hospital, London S.E.1.

‡ Present address: Barnes Hospital, Washington University School of Medicine, St. Louis, Missouri, U.S.A.

S Present address: Department of Pediatrics, University of Pennsylvania, Philadelphia, Pennsylvania, U.S.A.
Identification of the intracellular radioactive substances was obtained by paper chromatography of the water-soluble tissue extract, ethylacetate: pyridine: water $(12: 5: 4)$ being used as solvent. The developed chromatogram was cut into segments which were counted at $50 \%$ efficiency in a liquid scintillation spectrometer, the solvent used being $0.010 \% p-2^{\prime}-\left(5^{\prime}-\right.$ phenyloxazolyl) benzene and $0.457 \%$ 2,5-diphenyloxazole in toluene. The identity of the radioactive spots was determined by comparison of the $R_{f}$ found with that of appropriate standard markers similarly chromatographed. In order to prevent "tailing" of the radioactivity and to render the spots compact non-radioactive carrier of lactose and glucose were added to each chromatogram before development.

${ }^{14} \mathrm{CO}_{2}$ evolution from radioactive lactose by the tissue was measured by the method of Weinberg and Segal (1960). Lactase, maltase, and sucrase activities were determined by the technique of Dahlqvist (1964).

Selection of Patients. - Lactase-deficient patients were selected by obtaining a history of milk intolerance; these subjects also had gastrointestinal symptoms and lactose malabsorption after oral lactose-tolerance tests, as well as diminished lactase activity in mucosal biopsy specimens. Lactose malabsorption was based on a comparison of blood glucose changes after an oral load of $50 \mathrm{~g}$. of lactose compared with the glucose changes after a mixture of $25 \mathrm{~g}$. each of glucose and galactose (Auricchio et al., 1963 ; Cuatrecasas et al., 1965).

\section{Results}

The relevant clinical and laboratory details used to classify the two groups of subjects are given in Table I. Apart from one person (No. 5), all the control subjects were free of disease. No. 5 had male hypogonadism and had had a carcinoma of the rectum resected in 1965 ; at the time of this study there was no evidence of metastases. All the control individuals drank over $500 \mathrm{ml}$. of milk each day, except for No. 3, who took milk only with cereals. None had gastrointestinal symptoms either when they drank milk or during the lactose-tolerance tests, and all tested had a normal glucose response to the lactose load.

By contrast, the lactase-deficient patients had not drunk milk for many years, had symptoms of nausea or abdominal distension and cramps during the lactose test, and showed a "flat" lactose-tolerance curve but a normal response to the glucose-galactose mixture.

Table II shows the results of assays of lactase, sucrase, and, in most cases, maltase in the intestinal mucosal biopsy specimens. The results are expressed both as international units ( $\mu$ moles of disaccharide hydrolysed per minute) per gramme wet weight of tissue and as ratios of enzyme activities. It is apparent that the patients who on clinical grounds were presumed to be lactase-deficient have particularly low intestinal lactase activity when expressed both as absolute units and as sucrase-lactase ratios.

When the material obtained at biopsy was incubated with radioactive lactose there was a significantly lower uptake of radioactivity into lactase-deficient mucosa than into tissue from 
TABLE I.-Relevant Clinical Details of Subjects Included in Study and Results of Lactose-tolerance Tests

\begin{tabular}{|c|c|c|c|c|c|c|c|c|c|c|c|c|c|}
\hline \multirow{2}{*}{ No. } & \multirow{2}{*}{ Age } & \multirow{2}{*}{ Sex } & \multirow{2}{*}{$\underset{\text { Drinker }}{\text { Milk }}$} & \multicolumn{2}{|c|}{ Symptoms } & \multicolumn{4}{|c|}{ Lactose-tolerance Testt } & \multicolumn{4}{|c|}{ Galactose-glucose-tolerance Testt } \\
\hline & & & & Milk & Lactose & $0^{\prime}$ & $20^{\prime}$ & $40^{\prime}$ & $60^{\prime}$ & $0^{\prime}$ & $20^{\prime}$ & $40^{\prime}$ & $60^{\prime}$ \\
\hline \multicolumn{14}{|c|}{ Controls } \\
\hline $\begin{array}{l}1 \\
2 \\
3 \\
4 \\
5 \\
6^{*} \\
7^{*}\end{array}$ & $\begin{array}{l}21 \\
50 \\
50 \\
58 \\
57 \\
21 \\
21\end{array}$ & $\begin{array}{c}\mathrm{F} \\
\mathrm{F} \\
\mathrm{F} \\
\mathrm{F} \\
\mathrm{M} \\
\mathrm{M} \\
\mathrm{M}\end{array}$ & $\begin{array}{l}+ \\
+ \\
\pm \\
+ \\
+ \\
+ \\
+\end{array}$ & $\begin{array}{l}\bar{z} \\
\bar{z} \\
\bar{z} \\
\overline{-}\end{array}$ & $\begin{array}{l}\overline{-} \\
\overline{-} \\
\overline{-}\end{array}$ & $\begin{array}{r}88 \\
98 \\
107 \\
96 \\
91\end{array}$ & $\begin{array}{l}122 \\
144 \\
142 \\
118 \\
139\end{array}$ & $\begin{array}{l}122 \\
151 \\
128 \\
106 \\
125\end{array}$ & $\begin{array}{r}122 \\
130 \\
113 \\
88 \\
106\end{array}$ & $\begin{array}{r}80 \\
85 \\
102 \\
92\end{array}$ & $\begin{array}{r}116 \\
98 \\
148 \\
111\end{array}$ & $\begin{array}{r}105 \\
83 \\
150 \\
105\end{array}$ & $\begin{array}{r}92 \\
98 \\
113 \\
112\end{array}$ \\
\hline \multicolumn{14}{|c|}{ Lactase Deficiency } \\
\hline $\begin{array}{l}\text { I } \\
\text { II } \\
\text { II } \\
\text { V }\end{array}$ & $\begin{array}{l}48 \\
46 \\
65 \\
67 \\
61\end{array}$ & $\begin{array}{l}\mathrm{F} \\
\mathrm{F} \\
\mathrm{F} \\
\mathrm{F} \\
\mathbf{F}\end{array}$ & $\begin{array}{l}\bar{z} \\
\bar{z}\end{array}$ & $\begin{array}{l}+ \\
+ \\
+ \\
+ \\
+\end{array}$ & $\begin{array}{l}+ \\
+ \\
+ \\
+ \\
+\end{array}$ & $\begin{array}{l}87 \\
74 \\
86 \\
92 \\
80\end{array}$ & $\begin{array}{r}102 \\
70 \\
96 \\
89 \\
85\end{array}$ & $\begin{array}{r}106 \\
81 \\
96 \\
97 \\
83\end{array}$ & $\begin{array}{r}108 \\
88 \\
100 \\
98 \\
85\end{array}$ & $\begin{array}{l}93 \\
78 \\
90 \\
90 \\
84\end{array}$ & $\begin{array}{l}127 \\
108 \\
127 \\
114 \\
130\end{array}$ & $\begin{array}{l}144 \\
112 \\
137 \\
110 \\
137\end{array}$ & $\begin{array}{r}144 \\
116 \\
98 \\
90 \\
97\end{array}$ \\
\hline
\end{tabular}

* These subjects did not have lactose-tolerance tests performed. However, their tissue lactase levels were normal.
† Blood sugar in mg./100 ml. $\neq$ One quart $(1,140 \mathrm{ml}$.) of milk daily.

the control group after 30, 60, and 90 minutes (Table III). Though there was no difference in the radioactive content of the cell water between the two groups in the earlier time periods, paper chromotography of the 15- and 90-minutes incubation tissue extract showed that virtually all of the radioactivity was present as lactose in the lactase-deficient mucosa (Table IV). The material that was not lactose in the lactase-deficient cells was present only at the limits of detection at 15 minutes.

Table $\mathrm{V}$ shows the amount of ${ }^{14} \mathrm{CO}_{2}$ evolved by tissue incubated with radioactive lactose. Though the oxidation of lactose

TABLE II.-Results of Enzyme Assays of Mucosal Specimens

\begin{tabular}{|c|c|c|c|c|c|}
\hline \multirow{2}{*}{ No. } & \multicolumn{3}{|c|}{ Disaccharide Assays * } & \multirow{2}{*}{$\frac{\text { Sucrase }}{\text { Lactase }}$} & \multirow{2}{*}{$\frac{\text { Maltase }}{\text { Sucrase }}$} \\
\hline & Lactase & Sucrase & Maltase & & \\
\hline \multicolumn{6}{|c|}{ Controls } \\
\hline $\begin{array}{l}1 \\
2 \\
3 \\
4 \\
5 \\
6 \\
7\end{array}$ & $\begin{array}{l}3.0 \\
3.2 \\
3.8 \\
3.8 \\
3 \cdot 0 \\
4.7\end{array}$ & $\begin{array}{r}10.3 \\
5.4 \\
8.3 \\
12.5 \\
11.3 \\
10.0\end{array}$ & $\begin{array}{r}39.4 \\
24.0 \\
31.0 \\
46.5 \\
= \\
=\end{array}$ & $\begin{array}{l}3.4 \\
1.7 \\
2.2 \\
3.3 \\
3.6 \\
2.1\end{array}$ & $\begin{array}{l}3.8 \\
4.6 \\
3.7 \\
3.7 \\
= \\
=\end{array}$ \\
\hline \multicolumn{6}{|c|}{ Lactase-deficient } \\
\hline $\begin{array}{l}\text { II } \\
\text { III } \\
\text { IV } \\
\text { V }\end{array}$ & $\begin{aligned}<0.03 \\
<0.03 \\
0.16 \\
<0.03\end{aligned}$ & $\begin{array}{c}8.3 \\
15 \cdot 7 \\
18.9 \\
13.62\end{array}$ & $\begin{array}{l}38 \cdot 0 \\
56 \cdot 6 \\
72 \cdot 9 \\
= \\
-\end{array}$ & $\begin{array}{c}“ 276 " \\
" 523 " \\
11 \cdot 7 \\
“ 454 "\end{array}$ & $\begin{array}{l}4.6 \\
3.6 \\
3.9 \\
=\end{array}$ \\
\hline
\end{tabular}

Expressed as $\mu$ moles of disaccharide hydrolysed per minute per gramme we weight of mucosa.

TABLE III.-Distribution Ratios of Radioactivity Between Intracellular Water and Medium (Mean \pm S.E.)

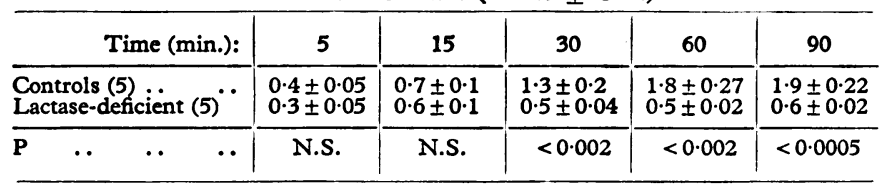

TABLE IV.-Percentage of Intracellular Radioactivity Remaining as

\begin{tabular}{|c|c|c|c|c|c|}
\hline $\begin{array}{l}\text { Time } \\
\text { (min.): }\end{array}$ & 15 & 90 & & 15 & 90 \\
\hline $\begin{array}{c}\text { Controls: } \\
1 \\
2 \\
5\end{array}$ & $\begin{array}{l}\overline{38} \\
44\end{array}$ & $\frac{58}{17}$ & $\begin{array}{c}\text { Lactase- } \\
\text { deficient: } \\
\text { II } \\
\text { III } \\
\text { V }\end{array}$ & $\begin{array}{l}98 \\
95 \\
98 \\
-\end{array}$ & $\begin{array}{l}88 \\
82 \\
90 \\
98\end{array}$ \\
\hline
\end{tabular}

TABLE V.-Evolution of ${ }^{14} \mathrm{CO}_{2}\left(m_{\mu} M / g\right.$. Wet Weight of Tissue $)$ from Lactose-1-14C (2 $\mathrm{mM})$ in Oxygenated Krebs-Ringer Bicarbonate Buffer at $37^{\circ} \mathrm{C}$.

\begin{tabular}{|c|c|c|c|c|c|c|c|c|c|}
\hline $\begin{array}{l}\text { Time } \\
\text { (min.): }\end{array}$ & 15 & 30 & 60 & 90 & & 15 & 30 & 60 & 90 \\
\hline $\begin{array}{c}\text { Controls: } \\
2 \\
3 \\
4 \\
7\end{array}$ & $\begin{array}{r}180 \\
58 \\
34\end{array}$ & $\begin{array}{l}109 \\
128 \\
160 \\
285\end{array}$ & $\begin{array}{l}398 \\
440 \\
294 \\
360\end{array}$ & $\begin{array}{l}556 \\
420 \\
392 \\
500\end{array}$ & $\begin{array}{c}\text { Lactase- } \\
\text { deficient: } \\
\text { II } \\
\text { III } \\
\text { V }\end{array}$ & $\begin{array}{l}60 \\
10 \\
25 \\
60\end{array}$ & $\begin{array}{r}\overline{46} \\
85 \\
100\end{array}$ & $\begin{array}{r}134 \\
157 \\
175 \\
95\end{array}$ & $\begin{array}{l}168 \\
185 \\
226 \\
122\end{array}$ \\
\hline
\end{tabular}

was less in the lactase-deficient patients than in the controls, it is noteworthy that some oxidation takes place even when there is no lactase activity demonstrable by enzymatic assay of the mucosal homogenate.

In three controls and two lactase-deficient patients mucosal incubations were done with sucrose $(2 \mathrm{mM})$ as well as lactose. In this group, all of whom had normal intestinal sucrase artivity, no differences were noted in intracellular uptake of radioactivity (Table VI).

In Table VII are shown the results of carrying out incubations with lactose in the presence of galactono- $\gamma$-lactone and also in sodium-free medium (tris-Krebs-Ringer buffer). In both instances a depression of uptake of radioactivity was found.

TABLE VI.-Comparison of Tissue Uptake of ${ }^{14} \mathrm{C}$ when Lactose or Sucrose was Used as Substrate in the Incubation Medium. Number Represent Distribution Ratios

\begin{tabular}{|c|c|c|c|c|c|c|c|c|c|}
\hline \multirow[t]{2}{*}{$\begin{array}{l}\text { Time } \\
\text { (min.): }\end{array}$} & 15 & 60 & 15 & 60 & & 15 & 60 & 15 & 60 \\
\hline & \multicolumn{2}{|c|}{ Lactose- ${ }^{14} \mathrm{C}$} & \multicolumn{2}{|c|}{ Sucrose $-{ }^{14} \mathrm{C}$} & & \multicolumn{2}{|c|}{ Lactose $-{ }^{14} \mathrm{C}$} & \multicolumn{2}{|c|}{ Sucrose- ${ }^{14} \mathrm{C}$} \\
\hline $\begin{array}{c}\text { Controls: } \\
1 \\
6 \\
7\end{array}$ & $\begin{array}{l}0.7 \\
0.5 \\
1.0\end{array}$ & $\begin{array}{l}2 \cdot 0 \\
1.5 \\
2 \cdot 0\end{array}$ & $\begin{array}{l}2.3 \\
1.4 \\
1 \cdot 9\end{array}$ & $\begin{array}{l}5.7 \\
3.9 \\
3.8\end{array}$ & $\begin{array}{c}\text { Lactase- } \\
\text { deficient: } \\
\text { I } \\
\text { III }\end{array}$ & $\begin{array}{l}0.4 \\
0.7\end{array}$ & $\begin{array}{l}0.5 \\
0.5\end{array}$ & $\begin{array}{l}2.6 \\
1.8\end{array}$ & $\begin{array}{l}7.6 \\
4.6\end{array}$ \\
\hline
\end{tabular}

TABLE VII.-Inhibition of 15-minute Uptake of Radioactivity in Normal Subjects

\begin{tabular}{|c|c|c|c|c|}
\hline \multirow{2}{*}{\multicolumn{2}{|c|}{ Patient No. : }} & 2 & 6 & 7 \\
\hline & & \multicolumn{3}{|c|}{$\%$ Inhibition of Control } \\
\hline $\begin{array}{l}\text { Galactono- } \gamma \text {-lactone } 10 \mathrm{mM} \text {. } \\
\text { Sodium-free medium } \ldots\end{array}$ & . & $\begin{array}{l}60 \\
60\end{array}$ & $\underline{45}$ & $\begin{array}{l}60 \\
30\end{array}$ \\
\hline
\end{tabular}

\section{Discussion}

The results indicate that in lactase deficiency there is less intracellular accumulation of radioactivity derived from the labelled lactose than there is in the normal. Chromatography of the intracellular extract shows that after 15 or 90 minutes incubation much of this radioactivity is no longer in the lactose moiety when normal tissue is studied. In the mucosa of the lactase-deficient patients there is, after 15 minutes' incubation, no metabolism of the lactose, while at 90 minutes only a minor amount has taken place. At no time does the lactose in the intracellular water of the lactase-deficient mucosa reach the same concentration as that present in the medium; the distribution ratio of the radioactivity, which is localized almost entirely in the lactose molecule, is consistently less than unity. Since the method for calculating the results allows for prior subtraction of radioactivity trapped in the extracellular water or inulin space of the cell (Rosenberg et al., 1961), it may be concluded that although the sugar has penetrated the cell it has not become evenly distributed through the cell water but is probably localized to a portion of the cell. 
The actual barrier to lactose diffusion into the whole cell has not been demonstrated, but the studies of Miller and Crane (1961a) suggest that the sugar is unable to enter into the cell without prior hydrolysis. It may be that in lactase deficiency the sugar can penetrate only as far as the cell membrane, where, in the absence of hydrolysis, it is trapped, since it appears that disaccharidase activity found at the brush border of the cell (Miller and Crane, 1961b ; Dahlqvist and Brun, 1962 ; Doell et al., 1965) is localized to the plasma membrane of the microvillus (Eichholz and Crane, 1965). By contrast, in the normal mucosa lactose passes into the membrane, where it is split into glucose and galactose, both of which are transported into the cell for further metabolism to take place. Support for this scheme comes from observations (Table VII) made when incubations were carried out in sodium-free medium, which depresses both lactase activity (Semenza and Auricchio, 1962; Prader et al., 1963) and monosaccharide transport (Bihler et al., 1962). Under these conditions there was a decreased amount of radioactivity entering the cell. Similarly, galactono- $\gamma$-lactone, a specific inhibitor of lactase (De La Fuente and Sols, 1962), also reduced the intracellular accumulation of radioactivity (Table VII). Furthermore, in the lactase-deficient tissue, where sucrase was present in normal amounts, there was no diminution in the uptake of radioactivity when sucrose rather than lactose was used as substrate (Table V).

The data obtained in this investigation do not of themselves resolve the question of whether in mammalian intestinal mucosal cells there is a $\beta$-galactoside permease as well as a $\beta$-galactoside hydrolase. In lactase deficiency there is no evidence that lactose may be taken into the cell against a concentration gradient. This, however, does not necessarily exclude the possibility of a specific permease-for example, one might postulate that in lactase deficiency there was loss of transporting as well as splitting enzyme. However, there is some evidence from animal studies that will not support this last hypothesis. Galactono$\gamma$-lactone, despite its action as an inhibitor of lactase, has no effect on galactose transport by small-intestinal mucosa of the adult rat (London and Cuatrecasas, 1966), which is virtually lacking in lactase activity (Doell and Kretchmer, 1962; Koldovský and Chytil, 1965). As all sugars that are actively transported have been shown to have a common "carrier" (Crane, 1960), the lack of inhibition on galactose transport would suggest a similar effect on lactose if the latter were actively transported. Furthermore, methyl- $\beta$ thiogalactoside, a sugar which shares many of the characteristics of lactose and is not split by lactase (Cohen and Monod, 1957), cannot be accumulated against a concentration gradient by the small-intestinal mucosa of the 1-week-old rat (London and Cuatrecasas, 1966), which does have lactase activity (Doell and Kretchmer, 1962 ; Koldovský and Chytil, 1965). Thus it appears that there is no intestinal permease for $\beta$-galactosides and that in the lactase-deficient state dissacharide that is not hydrolysed cannot be concentrated within the cell.

The deficiency in lactase activity, besides resulting in a limited uptake of carbohydrate by the mucosal cell, is also associated with a diminished oxidation of lactose. When the evolution of ${ }^{14} \mathrm{CO}_{2}$ from lactose- $1-{ }^{14} \mathrm{C}$ was measured, it was found that tissue that had low or absent lactase activity also produced less $\mathrm{CO}_{2}$ than normal mucosa. It is, however, noteworthy that the differences in $\mathrm{CO}_{2}$ evolution between the two groups are very much less than the differences in lactase activity. The three subjects with unmeasurably low lactase activity nevertheless display lactose oxidation which is $20-50 \%$ of normal. A possible explanation of this would be that the radioactive lactose contained some contaminant that was readily oxidized to $\mathrm{CO}_{2}$. However, neither paper chromatography nor highvoltage electrophoresis of the tracer compound showed any such impurity.

An alternative is that lactose may be metabolized by a route not requiring preliminary hydrolysis. Though no evidence for such a scheme has been reported for mammalian tissue, a bacterial lactose dehydrogenase has been described which can oxidize lactose to lactobionic acid (Nishizuka and Hayaishi, 1962). The possibility remains that such degradative systems may exist in mammalian tissue, including man.

\section{Summary}

The cellular transport and oxidation of lactose $-{ }^{14} \mathrm{C}$ was studied in peroral jejunal biopsy specimens of normal and isolated lactase-deficient adults. The mucosal cells of subjects with isolated lactase deficiency could not concentrate lactose against a concentration gradient and demonstrated reduced oxidation of lactose to $\mathrm{CO}_{2}$. The small amount of radioactivity entering the cells was virtually all lactose in the lactase-deficient mucosa, whereas lactose accounted for only a small amount of the intracellular radioactivity in the normal mucosa. Galactono$\gamma$-lactone and sodium-free medium, which inhibit lactase activity, suppressed the intracellular accumulation of lactose and its metabolic products in normal mucosa.

These studies suggest that the jejunal cell transport of disaccharides does not occur in the absence of hydrolysis and that no specific permeases exist which transport the dissacharides to the site of hydrolysis or to the intracellular space. Furthermore, the observation that mucosal specimens with unmeasurable lactase activity can nevertheless oxidize considerable lactose (20-50\% of normal) suggests that perhaps a hitherto unrecognized mode of lactose metabolism may exist which does not require initial hydrolysis of the lactose.

We are grateful to Drs. G. D. Aurbach, M. Lipsett, and S. Rosen, who allowed us to study patients under their care and normal control subjects.

\section{REFERENCES}

Auricchio, S., Rubino, A., Landolt, M., Semenza, G., and Prader, $A$ (1963). Lancet, 2, 324.

Bihler, I., Hawkins, K. A., and Crane, R. K. (1962). Biochim. biophys. Acta (Amst.), 59, 94.

Brandborg, L. L., Rubin, G. E., and Quinton, W. E. (1959). Gastroenterology, 37, 1 .

Cohen, G. N., and Monod, J. (1957). Bact. Rev., 21, 169

Cook, G. C., and Kajubi, S. K. (1966). Lancet, 1, 725.

Crane, R. K. (1960). Biochim. biophys. Acta (Amst.), 45, 477.

Cuatrecasas, P., Lockwood, D. H., and Caldwell, J. R. (1965). Lancet. $1,14$.

1, 14. 1 . (1964). Analyt. Biochem., 7, 18.

Dahlqvist, A. (1964). Analyt. Biochem., 7, 18. 42, 556.

and Brun, A. (1962). F. Histochem. Cytochem., 10, 294.

De La Fuente, G., and Sols, A. (1962). Biochim. biophys. Acta (Amst.) $56,49$.

Doell, R. G., and Kretchmer, N. (1962). Ibid., 62, 353.

- Rosen, G., and Kretchmer, N. (1965). Proc. nat. Acad. Sa. (Wash.), 54, 1268.

Durand, P. (1964). In Disorders Due to Intestinal Defective Carbo hydrate Digestion and Absorption, edited by P. Durand, p. 107. Rome.

Eichholz, A., and Crane, R. K. (1965). f. Cell. Biol., 26, 687.

Haemmerli, U. P., Kistler, H., Ammann, R., Marthaler, T., Semenzo G., Auricchio, S., and Prader, A. (1965).' Amer. f. Med., 38, 7.

Hsia, D. Y. Y., Makler, M., Semenza, G., and Prader, A. (1966). Biochim. biophys. Acta (Amst.), 113, 390

Koldovský, O., and Chytil, F. (1965). Biochem. F., 94, 266.

London, D. R., and Cuatrecasas, P. (1966). Unpublished observations.

McMichael, H. B., Webb, J., and Dawson, A. M. (1965). Lancet, 1, 717.

Miller, D., and Crane, R. K. (1961a). Biochim. biophys. Acta (Amst.) 52, 281 .

- (1961b). Ibid., 52, 293.

Nishizuka, Y., and Hayaishi, O. (1962). f. biol. Chem., 237, 2721

Peternel, W. W. (1965). Gastroenterology, 48, 299.

Prader, A., Semenza, G., and Auricchio, S. (1963). Schweiz. med. Wschr., 93, 1272.

Rickenberg, H. V., Cohen, G. N., Buttin, G., and Monod, J. (1956). Ann. Inst. Pasteur, 91, 829.

Rosenberg, L. E., Blair, A., and Segal, S. (1961). Biochim. biophys. Acta (Amst.), 54, 479.

Semenza, G., and Auricchio, S. (1962). 'bid., 65, 173.

- and Rubino, A. (1965). Ibid., 96, 487

Sheehy, T. W., and Anderson, P. R. (1965). Lancet, 2, 1.

Weinberg, A. N., and Segal, S. (1960). Science, 132. 1015 